\begin{tabular}{cc}
\hline INPAFI \\
\hline
\end{tabular}

\title{
PENGARUH MODEL PEMBELAJARAN BERBASIS MASALAH DENGAN MENGGUNAKAN MEDIA MIND MAPTERHADAP KEMAMPUAN PEMECAHAN MASALAH FISIKA SISWA PADA MATERI POKOK BUNYI DI KELAS VIII SMP NEGERI 2 SIDIKALANG T.P 2016/2017
}

\author{
Nurcahaya Sitanggang dan Ratelit Tarigan \\ Jurusan Fisika FMIPA Universitas Negeri Medan \\ cahayasitanggang71@yahoo.com, ratelittarigan@gmail.com
}

Diterima: Desember 2018. Disetujui: Januari 2019. Dipublikasikan: Februari 2019

\begin{abstract}
ABSTRAK
Penelitian ini bertujuan untuk mengetahui apakah ada pengaruh kemampuan pemecahan masalah fisika siswa dengan menggunakan model pembelajaran berbasis masalah dengan menggunakan media mind map daripada pembelajaran konvensional pada materi pokok bunyi di kelas VIII. Jenis penelitian ini adalah quasi experimen. Populasi dalam penelitian ini adalah seluruh siswa kelas VIII semester genap. Sampel penelitian ini diambil dua kelas yaitu kelas VIII-1 (sebagai kelas eksperimen) dan kelas VIII-2 (sebagai kelas kontrol) ditentukan dengan teknik cluster random sampling. Instrumen penelitian yang digunakan dalam bentuk tes uraian dengan jumlah 10 item yang telah divalidasi sesuai dengan standar soal yang baik. Perolehan data keterampilan siswa selama pembelajaran digunakan lembar observasi dengan 2 orang pengamat. Setelah dilakukan uji hipotesis diperoleh hasil belajar siswa pada kelas eksperimen lebih baik dari kelas kontrol, berarti ada pengaruh yang signifikan.
\end{abstract}

Kata Kunci: model pembelajaran berbasis masalah dan pembelajaran konvensional, kemampuan pemecahan masalah fisika siswa

\begin{abstract}
This study aims to determine whether there is influence of problem solving ability of physics student by using problem-based learning model by using mind-map media instead of conventional learning on the subject matter of sound in class VIII. This type of research is quasi exsperimen. The population in this study is all students of class VIII semester even. The sample of this research is taken by two classes that is class VIII-1 (as experiment class) and class VIII-2 (as control class) determined by cluster random sampling technique. The research instrument used in the form of a description test with a total of 10 items has been validated according to the standard of a good question. To obtain student skill data during the learning use observation sheet with 2 observers. After the hypothesis test, the students' learning outcomes in the experimental class is better than the control class, meaning there is a significant influence.
\end{abstract}

Keywords: problem basic learning, conventional learning, student physics problem solving ability 


\section{PENDAHULUAN}

Kualitas pendidikan di Indonesia masih jauh tertinggal bila dibandingkan dengan negara lain. Rendahnya daya saing sebagai indikator bahwa pendidikan belum mampu menghasilkan sumber daya manusia yang berkualitas. Hal ini dikarenakan sistem pendidikan di Indonesia masih bersifat Teacher Centered artinya pendidikan yang masih berorientasi kepada guru dan bukan kepada siswanya. Hasil observasi dan wawancara awal di SMPN 2 Sidikalang diperoleh data ulangan harian siswa pada pokok bahasan bunyi dengan persentase ketuntasan belajar $31 \%$. Dalam pembelajaran fisika di SMPN 2 Sidikalang dijumpai fakta-fakta sebagai berikut: 1) Metode pengajaran yang dominan adalah metode diskusi kelompok biasa (kooperatif reguler) dimana pembelajaran masih didominasi oleh guru serta siswa yang lebih mampu didalam masing-masing kelompok sehingga interaksi antar subyek belajar kurang intensif. 2) Guru lebih aktif dalam pembelajaran dan dianggap sebagai satu-satunya sumber belajar bagi siswa serta kurangnya alam sekitar yang dijadikan sumber belajar, walaupun sering berinteraksi dan ditemui dalam kehidupan, akibatnya siswa cenderung pasif, bosan sehingga kurang mengasah cara berpikir kritis dan kemampuan memecahkan masalah. 3) Banyak siswa beranggapan bahwa mata pelajaran fisika sulit, rumit, banyak rumus, bersifat abstrak dan teoritis serta penerapan dan manfaatnya sedikit dalam kehidupan manusia yang mengakibatkan kurangnya minat siswa terhadap mata pelajaran fisika.

Berdasarkan hal itu semua, maka sudah seharusnya bahwa fisika harus dipelajari secara menyenangkan dan menarik. Pembelajaran fisika berkaitan dengan kehidupan manusia yang menggantungkan hidupnya kepada alam. Fisika ditemukan dan dikembangkan berdasarkan masalah-masalah yang dihadapi manusia terkait dengan kehidupannya. Tampak bahwa sebetulnya fisika dianjurkan untuk dipelajari oleh setiap orang. Proses pembelajaran selama ini masih didominasi oleh guru sehingga belum memberikan kesempatan bagi siswa untuk berkembang secara mandiri melalui penemuan dan proses berpikir. Salah satu untuk mencapai hal tersebut adalah dengan mengubah model pembelajaran tradisonal menjadi model pembelajaran yang berpusat pada keaktifan siswa, dimana pada saat ini ada banyak model pembelajaran yang berpusat pada siswa dalam proses pembelajaran, misalnya adalah model pembelajaran berbasis masalah. Model pembelajaran berbasis masalah termasuk model pembelajaran yang dapat memacu semangat setiap siswa secara aktif ikut terlibat dalam pengalaman belajarnya, merupakan salah satu alternatif model pembelajaran yang memungkinkan dikembangkannya keterampilan berpikir siswa dalam memecahkan masalah. (Rusman, 2011).

Hasil seluruh peneliti yang menggunakan model pembelajaran berbasis masalah dapat menunjukkan peningkatan terhadap hasil belajar siswa. Pembelajaran berbasis masalah merupakan model pembelajaran yang dirancang membantu siswa mengembangkan keterampilan berfikir, keterampilan menyelesaikan masalah, keterampilan intelektualnya (Arends, 2008). Selain itu, pembelajaran berbasis masalah juga memilki beberapa kelemahan yang masih belum dapat diatasi salah satu diantaranya seperti, tidak memberikan waktu yang cukup bagi siswa untuk terlibat secara mendalam dalam kegiatan pembelajaran selain itu model ini tidak sesuai dengan kebanyakan informasi atau pengetahuan yang harus dipelajari karena guru masih banyak yang tidak memanfaatkan penggunaan model ini. Menggunakan mind map dalam model pembelajaran berbasis masalah dapat mempermudah pengajaran lebih efisien.. Menggunakan mind map siswa dapat memperoleh banyak informasi atau penjelasan. Mind map merupakan salah satu pembelajaran yang mampu mengembangkan berfikir dan menggunakan seluruh keterampilan siswa adalah dengan menggunakan mind map. Tony Buzan mengatakan " $A$ mind map powerful graphic technique which provides a universal key to unlock the potensial of the brain ". Mind map merupakan teknik grafik yang sangat ampuh dan menjadi kunci universal untuk membuka potensi 
Nurcahaya Sitanggang dan Ratelit Tarigan : Pengaruh Model Pembelajaran Berbasis Masalah Dengan Menggunakan Media Mind Map Terhadap Kemampuan Pemecahan Masalah Fisika Siswa Pada Materi Pokok Bunyi Di Kelas VIII SMP Negeri 2 Sidikalang T.P 2016/2017

dari seluruh otak karena menggunakan seluruh keterampilan.

Berdasarkan masalah di atas, penulis berkeinginan melakukan suatu penelitian untuk mengetahui kemampuan pemecahan masalah fisika siswa dengan menggunakan model pembelajaran berbasis masalah dengan menggunakan media mind map.

\section{METODE PENELITIAN}

Penelitian ini dilaksanakan di SMP Negeri 2 Sidikalang di Jalan Ki Hajar Dewantara, Kecamatan Sidikalang, Kabupaten Dairi. Waktu penelitian dilaksanakan pada bulan Januari sampai dengan April 2017. Subjek penelitian ini dikenakan pada siswa kelas VIII SMP Negeri 2 Sidikalang yang berjumlah 31 orang siswa. Jenis penelitian termasuk penelitian quasi experimen.

Penelitian ini melibatkan dua kelas yaitu kelas eksperimen dan kelas kontrol yang diberi perlakuan berbeda. Model berbasis masalah di kelas eksperimen, sedangkan pada kelas kontrol menggunakan pembelajaran konvensional. Desain penelitian ini dapat dilihat pada Tabel 1:

\section{Tabel 1.}

Two Group Pretest - Posttest Design

\begin{tabular}{|c|c|c|c|}
\hline Kelas & Pretest & Perlakuan & Postets \\
\hline Eksperimen & $\mathrm{T}_{1}$ & $\mathrm{X}$ & $\mathrm{T}_{2}$ \\
\hline Kontrol & $\mathrm{T}_{1}$ & $\mathrm{Y}$ & $\mathrm{T}_{2}$ \\
\hline
\end{tabular}

\section{Keterangan:}

$\mathrm{T}_{1}=$ Tes kemampuan awal (pretest)

$\mathrm{T}_{2}=$ Tes kemampuan akhir (postest)

$\mathrm{X}=$ Perlakuan pada kelas eksperimen yaitu penerapan model berbasis masalah

$\mathrm{Y}=$ Perlakuan pada kelas control yaitu

Penerapan model pembelajaran

konvensional

Peneliti memberikan pretes pada kelas eksperimen dan kelas kontrol. Instrumen yang digunakanpada penelitian adalah tes kemampuan pemecahan masalah terdiri dari 10 soal pilihan ganda. Tes kemampuan pemecahan masalah gunakan uji validitas isi oleh dua orang dosen dan satu guru sesuai dengan pakar ahlinya. Setelah data pretes diperoleh, dilakukan analisis data dengan uji normalitas yaitu uji liliefors, uji homogenitas dan uji kesamaan varians. Setelah itu dilakukan pengujian hipotesis uji $t$ untuk mengetahui kemampuan awal siswa pada kedua kelompok sampel dalam hal ini kemampuan awal kedua sampel tersebut harus sama. (Sudjana.2005).

Selanjutnya peneliti mengajarkan materi pelajaran dengan menggunakan model berbasis masalah pada kelas eksperimen dan pembelajaran konvensional pada kelas kontrol. Perbedaan hasil akhir dapat diketahui dengan dilakukan postes menggunakan uji t satu pihak mengetahui pengaruh perlakuan model berbasis masalah terhadap kemampuan pemecahan masalah siswa. ( Mushon, 2014).

\section{HASIL DAN PEMBAHASAN}

\section{a. Hasil Penelitian}

Data yang dideskripsikan pada penelitian ini meliputi data kemampuan berpikir kritis siswa belajar fisika pada materi fluida statis, yang diberikan perlakuan berbeda yaitu 1) model berbasis masalah, 2) pembelajaran dengan menggunakan pembelajaran konvensional. Hasil data pretest siswa kelas eksperimen dan kelas kontrol dapat ditunjukkan pada Gambar 1:

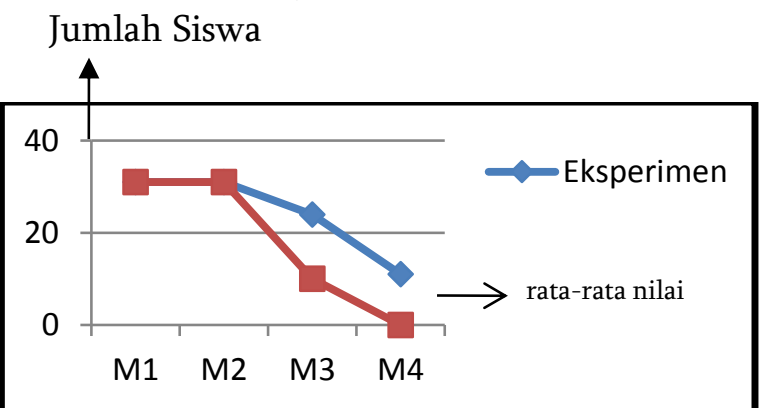

Gambar 1. Data pretest kelas eksperimen dan kontrol

\section{Keterangan :}

$\mathrm{M}_{1}=$ Memahami Masalah

$\mathrm{M}_{2}=$ Menyusun Rencana/Memilih Strategi

$\mathrm{M}_{3}=$ Melaksanakan Strategi dan mendapatkan

hasil

$\mathrm{M}_{4}=$ Memeriksa Proses dan Hasil

Gambar 1 menunjukkan bahwa nilai pretes pada kelas eksperimen dan kelas kontrol 
memiliki nilai yang sangat rendah. Nilai kelas kontrol sedikit lebih tinggi dibandingkan dengan kelas eksperimen perbandingan rata-rata untuk memahami masalah yaitu 19,19 dan 18,09 . Untuk menyusun rencana dan memilih strategi kelas kontrol lebih rendah daripada kelas eksperimen yaitu 14,25 dan 15,96. Kriteria melaksanakan strategi dan mendapatkan hasil kelas kontrol lebih rendah dibandingan kelas eksperimen yaitu 2,93 dan 5,45 dan untuk kriteria memeriksa proses dan hasil keras kontrol tidak ada yang tuntas sementara kelas eksperimen sebesar 0.09.

Setelah dilakukan perhitungan atas nilai rata - rata keterampilan siswa maka nilai rata -rata siswa dapat dilihat pada Gambar 2 sebagai berikut:

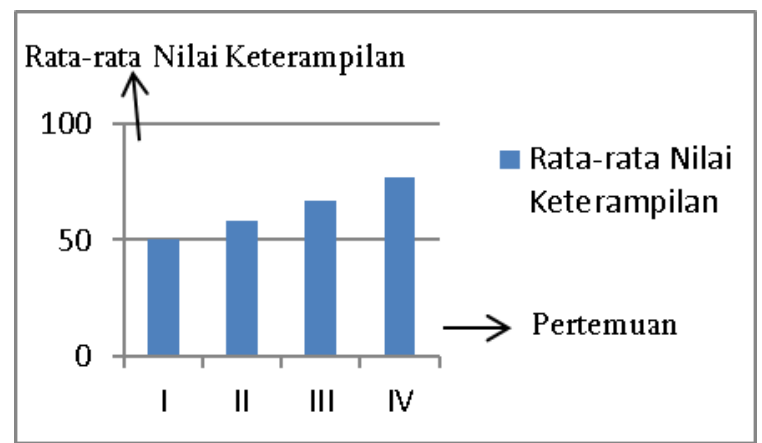

Gambar 2. Rata-Rata Nilai Keterampilan siswa

Berdasarkan Gambar 2 diperoleh keterampilan siswa pada pertemuan I tergolong kurang aktif (50\%). Peneliti memberi saran dan arahan kepada siswa hingga siswa paham dan termotivasi dalam belajar. Pertemuan II terjadi peningkatan keterampilan siswa menjadi 58\% yaitu pada kategori cukup aktif. Pertemuan III juga terjadi peningkatan keterampilan siswa menjadi $67 \%$ yaitu pada kategori cukup aktif. Pertemuan ke IV terjadi peningkatan keterampilan siswa menjadi $77 \%$ tergolong kategori aktif. Ternyata keterampilan siswa sejalan dengan peningkatan kemampuan pemecahan masalah fisika siswa. Dalam hal ini keterampilan siswa memiliki pengaruh positif terhadap kemampuan pemecahan masalah fisika siswa.
Setelah dilakukan penghitungan data dikelas kontrol dan kelas eksperimen sesuai dengan pedoman penskoran dalam kemampuan pemecahan masalah maka diperoleh hasil nilai siswa yang terdapat pada Gambar 3 sebagai berikut.

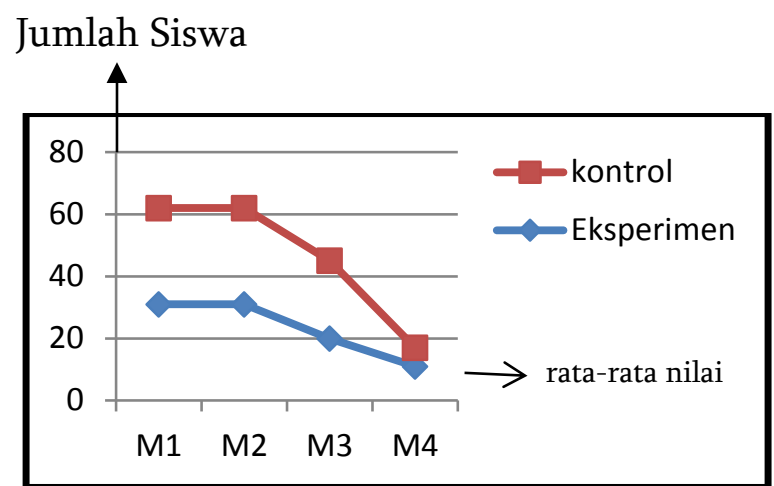

Gambar 3. Data posttes kelas eksperimen dan kontrol

\section{Keterangan :}

$\mathrm{M}_{1}=$ Memahami Masalah

$\mathrm{M}_{2}=$ Menyusun Rencana/Memilih Strategi

$\mathrm{M}_{3}=$ Melaksanakan Strategi dan Mendapatkan hasil

$\mathrm{M}_{4}=$ Memeriksa Proses dan Hasil

Dari gambar 3 diperoleh akibat adanya pengaruh dari model yang diberikan, pada saat memasuki tahap melaksanakan strategi dan mendapatkan hasil hasil semua siswa dapat mencapai proses yaitu 31 siswa yang mampu menyelesaikan sedangkan pada saat tahap memeriks proses dan hasil hanya 11 siswa yang dapat menyelesaikan soal tersebut. Hal ini kemampuan pemecahan masalah fisika dengan menggunakan model pembelajaran berbasis masalah dengan media mind map pada materi pokok bunyi tergolong baik karena adanya peningkatan setelah siswa diberikan model pembelajaran dan rata -rata siswa mengalami ketuntasan atau mencapai nilai ketuntasan.

\section{b. Pembahasan}

Pembelajaran berbasis masalah yaitu guru menyodorkan situasi-situasi bermasalah kepada siswa dan memerintahkan mereka untuk menyelidiki dan menemukan sendiri solusinya. Pembelajaran berbasis masalah juga bertujuan 
Nurcahaya Sitanggang dan Ratelit Tarigan : Pengaruh Model Pembelajaran Berbasis Masalah Dengan Menggunakan Media Mind Map Terhadap Kemampuan Pemecahan Masalah Fisika Siswa Pada Materi Pokok Bunyi Di Kelas VIII SMP Negeri 2 Sidikalang T.P 2016/2017

membantu siswa mengembangkan kemampuan investigasi dan kemampuan mengatasi masalah, memberikan pengalaman peran orang dewasa kepada siswa dan memungkinkan siswa untuk mendapatkan rasa percaya diri atas kemampuannya sendiri untuk berfikir dan menjadi pelajar.(Arend, 2008).

Menurut penelitian yang terdahulu Ajeng Utrifani (2014) dengan menggunakan problem based learning pada materi pokok kinematika gerak lurus dari hasil penelitian terjadi pengaruh dari model pembelajaran problem based learning bahwa nilai post-test dikelas eksperimen $74,97 \%$ lebih tinggi dibandingkan dengan nilai post-test dikelas kontrol $69,87 \%$ dari hasil observasi tersebut dapat disimpulkan bahwa model pembelajaran berbasis masalah dapat meningkatkan aktivitas belajara siswa pada materi pokok kinematika gerak lurus. Menurut penelitian Lestari (2014) dengan menggunakan model pembelajaran problem based learning terhadap prestasi belajar fisika bagi siswa kelas VII SMP bahwa penelitian juga memperoleh hasil penelitian bahwa hasil belajar dikelas eksperimen lebih tinggi dibandingkan di kelas kontrol terbukti dari hasil post-test di kelas eksperimen 77,66\% sedangkan kelas kontrol $73,44 \%$. Kesimpulan yang sama juga diperoleh dari penelitian Dewi,dkk bahwa Hasil penelitian menunjukkan (1) terdapat perbedaan kemampuan pemecahan masalah antara kelompok siswa yang belajar melalui model PBL dengan kelompok siswa yang belajar melalui model pembelajaran langsung (2) terdapat perbedaan kemampuan pemecahan masalah antara kelompok siswa yang belajar melalui model PBL dengan siswa yang belajar melalui model pembelajaran langsung setelah dilakukan pengendalian terhadap skor bakat numerik dan (3) terdapat kontribusi bakat numerik terhadap kemampuan pemecahan masalah dan dari penelitian Elnethra,dkk (2013) bahwa penelitian dengan menggunakan PBL berpengaruh meningkatkan skor hasil belajar siswa. Hasil penelitin Sunarno (2012) mengungkapkan pembelajaran fisika berbasis masalah efektif digunakan untuk meningkatkan hasil belajar kognitif, afektif dan psikomotorik siswa.

Hasil penelitin Jauhariyah (2012) menungkapkan pembelajaran fisika berbasis masalah efektif digunakan untuk meningkatkan hasil hasil belajar kognitif, afektif dan psikomotorik siswa. Begitupun dengan Safitri, (2014) mengemukakan bahwa adanya hubungan yang positif dan signifikan antara kemampuan berfikir kreatif dan motivasi dengan hasil belajar melalui model Problem Based Learning.

Terdapat beberapa fase-fase yang ada pada pembelajaran berbasis masalah. Tahap orientasi siswa pada masalah (pertama), peneliti memotivasi siswa dengan memberikan tujuan pembelajaran yang akan dicapai oleh siswa dan pada tahap ini peneliti memberikan masalah kepada siswa dengan memberikan pertanyaan sederhana yang berbeda didalam kehidupan sehari-hari siswa. Tahap mengorganisasi siswa untuk belajar (kedua), peneliti memberikan materi pelajaran dengan bantuan media mind map yang dipelajari kemudian membentuk kelompok-kelompok belajar dan melakukan percobaan (eksperimen). Tahap penyelidikan individual maupun kelompok (ketiga), peneliti membimbing setiap siswa untuk mengumpulkan informasi untuk memecahkan masalah, dan melakukan percobaan (eksperimen) sekali lagi. Tahap mengembangkan dan mempresentasikan artefak dan exhibit (keempat), peneliti membantu setiap kelompok menyelesaikan dan menjawab semua permasalahan yang ada, serta mempersentasikan hasil diskusi kelompok yang sudah disiapkan, kemudian kelompok yang lain diberikan kesempatan memberikan pendapat atau masukan. Tahap menganalisis dan mengevaluasi proses mengatasi masalah (kelima), peneliti membantu siswa dalam mengkaji ulang pemecahan masalah sesuai dengan tujuan pembelajaran dan memberikan penguatan pada pemecahan masalah tersebut dan pada tahap ini peneliti membuat tes evaluasi untuk mengetahui pemahaman siswa .

Sesuai dengan teori belajar yang mendukung antara Vigotsky, Piaget dan Bruner. Seperti Vigotsky dan Piaget mengatakan bahwa 
pedagogik yang baik itu harus melibatkan siswa,dengan situasi-situasi yang melakukan eksperimen serta pembelajaran terjadi melalui interaksi antara siswa dengan teman sebaya dengan tantangan dan bantuan yang sesuai dari guru dan teman sebaya yang lebih mampu. Sedangkan pendapat dari Bruner mengatakan bahwa interaksi sosial didalam dan diluar sekolah menyumbangkan banyak perolehan bahasa siswa dan perilaku-perilaku pemecahan masalah. Sehingga semua berhubungan antara lingkungan sekolah dan lingkungan luar yang mampu menambah wawasan siswa dalam berfikir, bertingkah laku, maupun menyelesaikan masalah-masalah yang ada dalam kehidupan sehari-hari.

Penelitian ini kelebihan yang dapat diberikan dengan menggunakan model pembelajaran berdasarkan masalah dengan menggunakan media mind map untuk membantu siswa mengembangkan kemampuan berpikir, pemecahan masalah, dan keterampilan intelektual: belajar berbagai peran orang dewasa melalui pelibatan mereka dalam pengalaman nyata atau simulasi; dan menjadi pembelajar yang otonom dan mandiri. Langkah-langkah pembelajaran pada model PBM mendorong siswa untuk lebih aktif di dalam kelas. Misalnya pada saat mengerjakan lembar Kerja Siswa (LKS), siswa dibagi ke dalam kelompok yang hanya beranggotakan 4 sampai 5 orang siswa, mengerjakan LKS selama 35 menit, kemudian mempresentasikan hasil diskusi kepada temanteman yang lain. Lembar kerja siswa ini mendorong siswa untuk lebih berpartisivasi dalam kerja kelompoknya. Hal yang paling penting dalam model pembelajaran ini adalah adanya reward yang diberikan kepada kelompok yang terbaik. Reward ini juga salah motivasi bagi siswa untuk selalu memberikan yang terbaik dalam kelompoknya masing masing.

Kegiatan pembelajaran disetiap pertemuannya, peneliti sebagai guru yang menerapkan model pembelajaran berusaha menerapkan rencana pembelajaran sesuai dengan alokasi waktu yang tersedia, tetapi selama pembelajaran masih ada kendala yang dihadapi peneliti. Kendala-kendala yang dihadapi yaitu kondisi kelas sulit dikontrol karena kesempatan diskusi dalam proses pembelajaran memberi peluang bagi beberapa siswa untuk ribut sehingga mengganggu kerja kelompok yang lain, LKS siswa tidak sepenuhnya terisi, selain itu alokasi waktu yang terbatas, sehingga hasil diskusi tidak semua kelompok dapat dikomukasikan di depan kelas.

\section{KESIMPULAN DAN SARAN}

\section{Kesimpulan}

Berdasarkan hasil penelitian yang diperoleh dari hasil analisa data dan pengujian hipotesis maka dapat disimpulkan bahwa hasil belajar siswa pada kelas eksperimen lebih baik dari hasil belajar kelas kontrol, berarti ada pengaruh yang signifikan akibat model pembelajaran berbasis masalah dengan media mind map terhadap kemampuan belajar fisika siswa pada materi pokok Bunyi di kelas VIII.

\section{Saran}

Pelaksanaan model pembelajaran ini masih banyak kelemahan dan kendala yang dihadapi peneliti sehingga keterlaksanaan model ini tidak sepenuhnya tercapai. Berdasarkan pembahasan hasil penelitian maka sebagai tindak lanjut dari penelitian ini disarankan kepada peneliti selanjutnya diharapkan lebih mamapu memfokuskan siswa pada saat melakukan percobaan/praktikum dengan lebuh tegas mengarahkan siswa terutama dalam prosedur percobaan langsung dan juga diharapkan untuk peneliti selanjutnya diharapkan membuat jumlah siswa dalam setiap kelompok cukup 3-4 orang agar semua siswa dapat bekerja dan berperan aktif dalam setiap kelompok. Diharapkan untuk meningkatkan ketuntasan belajar siswa , sebaiknya siswa lebih aktif, percaya diri dan berusaha untuk menggali pemikiran dalam mencari informasi pada kegiatan pembelajaran sehingga termotivasi dan menyukai suatu mata pelajaran khususnya IPA sehingga dapat mencapai ketuntasan belajar maksimal.

\section{DAFTAR PUSTAKA}


Nurcahaya Sitanggang dan Ratelit Tarigan : Pengaruh Model Pembelajaran Berbasis Masalah Dengan Menggunakan Media Mind Map Terhadap Kemampuan Pemecahan Masalah Fisika Siswa Pada Materi Pokok Bunyi Di Kelas VIII SMP Negeri 2 Sidikalang T.P 2016/2017

Arends, R. I., (2008), Learning to Teach (Belajar untuk Mengajar), Pustaka Pelajar, Yogyakarta.

Dewi, S, S, (2014), Pengaruh Model Pembelajaran Problem Based Learning Terhadap Kemampuan Pemecahan masalah Fisika Melalui Pengendalian Bakat Numerik, e-Journal Pasca Sarjana Universitas Pendidikan Ganesha 4, (2), 1-11

Elnetthra, F., (2013), The Role of PBL in Improving Physics Students Creative Thinking and its Imprint on Gender, journal Universitas Malaysia 1, (1), 110.

Jauhariyah, M.N.R.,Sarwanto., \& Suparmi., (2012), Pengembangan Modul Fisika Berbasis Problem Based Learning Pada Materi Fluida Untuk Siswa Cerdas Istemewa-Berbakat Istimewa,Jurnal Program Pascasarjana Universitas Sebelas Maret, 3 (2), 11-21

Lestari, (2012). Pengaruh Model Pembelajaran Berbasis Masalah (Problem- Based Learning) dan Motivasi Belajar Terhadap Prestasi Belajar Fisika Bagi Siswa Kelas VII SMP. Jurnal Teknologi Pembelajaran Program Pasca Sarjana Universitas Pendidikan Ganesha Singaraja, Singaraja., tidak dipublikasi

Mushon, A. 2009. Peningkatan Minat Belajar dan Pemahaman Mahasiswa Melalui Penerpan Problem-Based Learning. Jurnal Pendidikan, 39, (2) , 14-26

Rusman, (2011). Model Pembelajaran Mengembangkan Profesionalisme Guru. Jakarta: PT. Rajagrafndo Persada.

Safitri, L.A., Rosidin, U., \& Ertikanto., (2014), Hubungan Kemampuan Berfikir Kreatif dan Motivasi Dengan Hasil Belajar
Melalui Model PBL, Jurnal Pembelajaran Fisika 2, (3 ), 1-11

Sudjana, (2005), Metoda Statistika, Tarsito, Bandung.

Trianto, (2009), Mendesain Model Pembelajaran Inovatif-Progresif, Kencana Prenanda Media Group, Jakarta.

Utrifani,A., (2014), Pengaruh Model Pembelajaran Problem Based Learning Terhadap Hasil Belajar Siswa SMA Pada Materi pokok Kinematika Gerak Lurus kelas X SMA Negeri 14 Medan T. P. 2013 / 2014, Jurnal Inpafi 2, (2), 9-16.

Wardhani, K., Sunarno, W.,\& Suparmi., (2012), Pembelajaran Fisika dengan Model Problem Based Learning Menggunakan Multimedia dan Model Ditinjau dari Kemampuan Verbal Siswa. Jurnal Pendidikan Sains Prodram Pasca Sarjana Universitas Sebelas Maret Surakarta, 1, (2), 163-169 ISSN 2252-7893, Surakarta. Tersedia http://jurnal.pasca.uns.ac.id 